J. Lake Sci. (湖泊科学), 2012, 24(4): 593-599

http: //www.jlakes.org. E-mail: jlakes@niglas.ac.cn

(C) 2012 by Journal of Lake Sciences

\title{
赣江下游流域大型底栖动物群落结构及水质生物学评价*
}

\author{
丁建华 ${ }^{1}$, 杨 威 ${ }^{1}$, 金显文 ${ }^{1}$, 邓道贵 ${ }^{1 * *}$, 葛 茜 $^{1}$, 刘足根 ${ }^{2}$ \\ (1: 淮北师范大学生命科学学院资源植物生物学安徽省重点实验室,淮北 235000) \\ (2: 江西省环境保护科学研究院,南昌 330029)
}

\begin{abstract}
摘 要: 2009 年 6 月 (丰水期)、11 月 (枯水期) 和 2010 年 4 月 (平水期) 对赣江下游流域大型底栖动物群落结构进行调查 研究, 共鉴定出大型底栖动物 3 门 15 科 25 种. 结果表明, 赣江下游流域大型底栖动物群落结构具有明显的时空变化. 生 物密度最大值 $\left(145.9 \pm 81.8 \mathrm{ind} . / \mathrm{m}^{2}\right)$ 出现在 6 月, 最小值 $\left(89.6 \pm 15.9 \mathrm{ind} . / \mathrm{m}^{2}\right)$ 出现在 4 月; 生物量的变化则相反, 最大 值 $\left(90.1 \pm 25.4 \mathrm{~g} / \mathrm{m}^{2}\right)$, 出现在 4 月, 最小值 $\left(62.9 \pm 20.9 \mathrm{~g} / \mathrm{m}^{2}\right)$ 出现在 6 月; 干流的生物密度在 6 月、11 月和 4 月均明显 高于支流, 而生物量在 11 月低于支流. Shannon-Wiener 多样性指数 $\left(H^{\prime}\right) 、$ Margalef 丰富度指数 $(D)$ 和 Pielou 均匀性指数 $(J)$ 在 6 月、 11 月和 4 月的时间尺度上以及干流、支流的空间尺度上均出现明显的变化,在 11 月份, 这 3 类指数均表现为 最高, 6 月则均为最低; 干流的 $H^{\prime}$ 和 $D$ 在 6 月和 4 月均低于支流, 而 $J$ 在这 3 个时间段内则均是支流高于干流, 表明支流 大型底栖动物的群落结构较干流更为多样、均匀和稳定. $H^{\prime}$ 和 $D$ 的结果表明赣江下游流域水质均受到不同程度的污染, 其中干流的污染程度较支流更为严重.
\end{abstract}

关键词: 贑江下游流域; 大型底栖动物;群落结构;水质生物学评价

\section{Community structure of macrozoobenthos and biological evaluation of water quality in lower reaches of Ganjiang River}

\author{
DING Jianhua $^{1}$, YANG Wei ${ }^{1}$, JIN Xianwen ${ }^{1}$, DENG Daogui ${ }^{1}$, GE Qian $^{1} \&$ LIU Zugen ${ }^{2}$ \\ (1: Anhui Key Laboratory of Resource and Plant Biology, School of Life Sciences, Huaibei Normal University, Huaibei \\ 235000, P. R. China) \\ (2: Jiangxi Academy of Environmental Sciences, Nanchang 330029, P. R. China)
}

\begin{abstract}
Macrozoobenthos community structure in the lower reaches of Ganjiang River was investigated in June (wet season) and November (dry season) 2009 and April (normal-water period) 2010. A total of 25 species from 15 families were recorded. Results showed that temporal and spatial variations of the macrozoobenthos community structure were obvious in the lower reaches of Ganjiang River. The mean maximal density $\left(145.9 \pm 81.8\right.$ ind $\left./ \mathrm{m}^{2}\right)$ occurred in June while the minimum $\left(89.6 \pm 15.9\right.$ ind. $\left./ \mathrm{m}^{2}\right)$ appeared in April. On the contrary, the mean maximal biomass $\left(90.1 \pm 25.4 \mathrm{~g} / \mathrm{m}^{2}\right)$ occurred in April while the minimum $(62.9 \pm$ $20.9 \mathrm{~g} / \mathrm{m}^{2}$ ) appeared in June. Their mean densities in the main stream were always higher than those in branches. However, the mean biomass in main stream was lower than that in branches in November. Temporal and spatial variations of three indices (including Shannon-Wiener index, Margalef index and Pielou evenness index) were apparent. Maximal values of all the indices occurred in November while the minimum appeared in June. The Shannon-Wiener index and Margalef index in the main stream were lower than those in branches in June and April; however, the Pielou evenness index in branches was constantly higher than that in the main stream, which showed that the community structure of macrozoobenthos in branches was more diversiform, uniform, and stable than that in the main stream. According to Shannon-Wiener index and Margalef index, the lower reaches of Ganjiang River was polluted to a certain extent and the main stream was more serious.
\end{abstract}

Keywords: Lower reaches of Ganjiang River; macrozoobenthos; community structure; biological evaluation of water quality

* 国家水体污染控制与治理科技重大专项项目 (2008ZX07526-008) 资助. 2011-08-10 收稿;2011-11-06 收修改 稿. 丁建华, 男, 1979 年生, 博士; E-mail:jianhuad2004@gmail. com.

** 通信作者;E-mail :dengdg@263.net. 
底栖动物是指生活史的全部或者大部分时间生活于水体底部的水生动物群, 通常将不能通过 $0.5 \mathrm{~mm}$ (约 40 目) 孔径网笁、体长 $\geqslant 1 \mathrm{~mm}$ 的底栖动物称为大型底栖动物 ${ }^{[1-2]}$, 它们是构成整个淡水生态系统的重要 组成部分. 在应用上, 底栖动物不仅是鱼类等经济水生生物的天然食料, 同时也常被作为环境监测的生物指 标 $^{[1,3]}$, 其群落结构、生物多样性大小等指标与水质状况密切相关 ${ }^{[1]}$.

赣江是长江流域的主要支流, 也是江西省第一大河, 发源于闽、赣交界的武夷山区, 自南向北流经赣州、 万安、吉安、樟树等 20 多个县市至南昌市, 分四支注人鄱阳湖, 干流全长 $766 \mathrm{~km}$. 赣州市以上为上游, 称贡 水, 长 $255 \mathrm{~km}$, 在赣州市城北与章水汇合后, 始称赣江; 赣州市至新干县城为中游, 长 $303 \mathrm{~km}$; 新干县城至吴 城县城为下游, 长 $208 \mathrm{~km}$. 袁河、锦江为赣江下游的主要支流. 赣江流域属中亚热带湿润季风气候, 年降水量 $1400 \sim 1800 \mathrm{~mm}$, 人鄱阳湖泥沙量年均 $1140 \times 10^{4} \mathrm{t}^{[4]}$.

目前, 仅有赣江支流袁河的底栖动物的调查研究 ${ }^{[5]}$, 而有关整个赣江下游大型底栖动物的调查研究尚 未见报道. 本文通过对赣江下游大型底栖动物群落结构的调查研究, 揭示其群落结构在不同时期及不同河 段的时空分布和变化特征, 有助于深人了解河流生态系统的结构特征与变化趋势, 亦可为赣江渔业、水环境 监控和综合治理提供一定的理论依据.

\section{1 材料与方法}

\section{1 采样时间和采样点设置}

2009 年 6 月 (丰水期)、11 月 (枯水期) 和 2010 年 4 月 (平水期) 对江西省赣江下游的干流、支流进行大 型底栖动物采样调查. 根据赣江下游自然环境的特点, 共设置 30 个采样点 (图 1), 其中袁河 (一级支流) 10 个采样点 (1. 龙王潭;2. 林家坊;3. 下浦; 4 . 涁江;5. 湖心岛;6. 江口码头 (仙女湖);7. 浮桥; 8 . 罗坊; 9. 下蒋家; 10. 荷湖馆), 锦江 (一级支流) 5 个采样点 (11. 万载均车; 12 . 上高饮用水源地; 13 . 良田沙场; 14. 高邮渡口; 15. 厚田沙漠), 干流 15 个采样点 (16. 峡江彭家; 17. 新干张家渡; 18. 樟树码头; 19. 丰城肖 江路口;20. 丰城拖船埠;21. 丰城小港口;22. 生米大桥;23. 朝阳水厂;24.八一桥;25. 西河;26. 滁槎; 27. 吉里;28. 周坊;29. 昌邑;30. 吴城港), 所有采样点均经 GPS 定位. 各采样点的理化性质见表 1 .
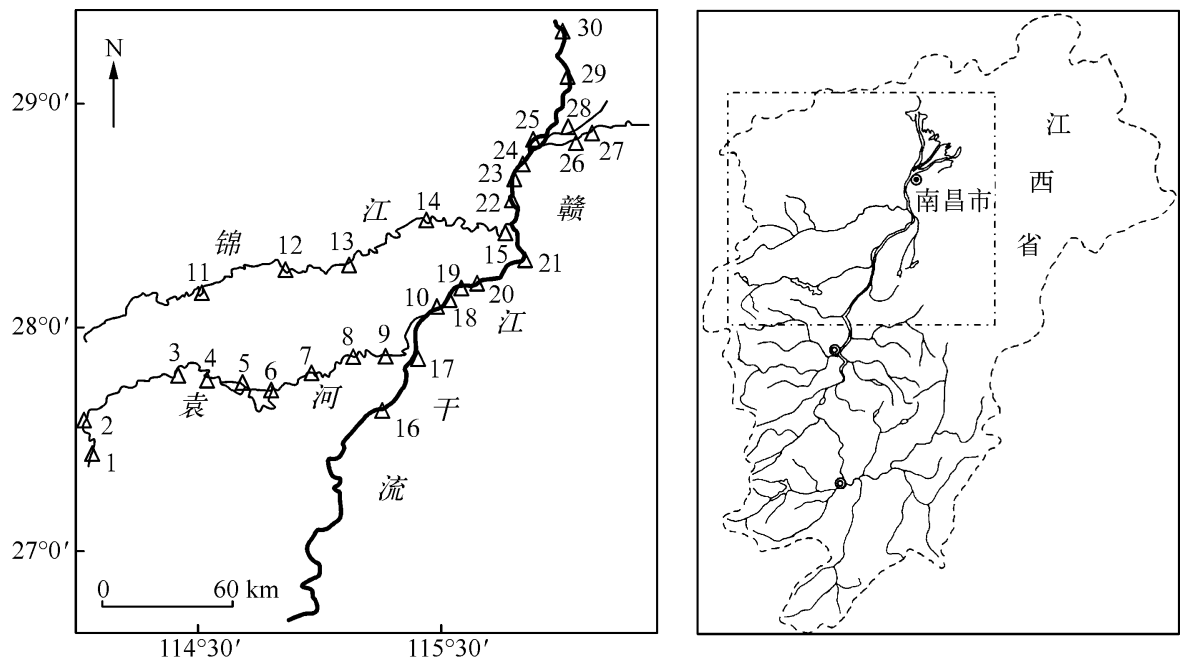

图 1 赣江下游采样点位置

Fig. 1 The location of sampling sites in lower reaches of Ganjiang River

\section{2 样品的采集与鉴定}

采用改良的彼得森采泥器 (有效采集面积为 $0.074 \mathrm{~m}^{2}$ ) 在船上进行样品采集. 在每个采集断面, 根据河 段的宽度, 在距离岸边 $1 / 3$ 处设立 3 个采集点, 每个采集点进行 3 次有效采样 (即在由于石块、树枝等杂物 的妨碍使得采泥器无法有效合拢而出现泥样洒漏的情况下, 必须进行重新采样). 所采泥样经 40 目笁网滤 
洗后进行现场挑拣, 挑拣出来的标本用 $10 \%$ 的福尔马林溶液固定, 然后带回实验室鉴定. 用滤纸吸去标本表 面的固定液, 置于电子天平上进行称重 (精确度为 $0.0001 \mathrm{~g}$ ), 计算单位面积的生物密度和生物量 ( 以鲜重 计). 并对那些由于水流湍急或其它原因而无法进行有效采集样品的点位进行剔除, 其中丰水期和平水期均 剔除了 $16^{\#} 、 21^{\#}$ 样点; 枯水期剔除了 $15^{\#}$ 样点. 所采集样品的鉴定参照相关文献 ${ }^{[6-9]}$.

表 1 赣江下游流域水体理化性质*

Tab. 1 The physical and chemical properties of the water in lower reaches of Ganjiang River

\begin{tabular}{ccccccc}
\hline \multirow{2}{*}{ 理化指标 } & \multicolumn{2}{c}{2009 年 11 月 } & & \multicolumn{2}{c}{2010 年 4 月 } \\
\cline { 2 - 3 } \cline { 6 - 7 } & 干流 $(n=15)$ & 支流 $(n=14)$ & & 干流 $(n=13)$ & 支流 $(n=15)$ \\
\hline 水温 $/{ }^{\circ} \mathrm{C}$ & $17.57 \pm 1.06$ & $16.87 \pm 0.88$ & & $16.59 \pm 0.12$ & $16.10 \pm 0.35$ \\
$\mathrm{pH}$ & $7.05 \pm 0.07$ & $7.16 \pm 0.07$ & & $6.61 \pm 0.04$ & $7.04 \pm 0.11$ \\
溶解氧 $/(\mathrm{mg} / \mathrm{L})$ & $9.37 \pm 0.10$ & $9.47 \pm 0.16$ & & $7.01 \pm 0.05$ & $7.25 \pm 0.12$ \\
浊度 $/ \mathrm{NTU}$ & $69.20 \pm 11.34$ & $29.43 \pm 4.87$ & & $83.67 \pm 23.20$ & $34.15 \pm 8.82$ \\
采集点处河流宽度 $/ \mathrm{m}$ & $234.67 \pm 29.03$ & $142.14 \pm 69.24$ & & $342.36 \pm 33.40$ & $155.66 \pm 63.71$ \\
采集点处河流深度/m & $4.21 \pm 0.83$ & $3.53 \pm 0.27$ & & $6.04 \pm 0.41$ & $4.80 \pm 0.40$ \\
\hline
\end{tabular}

* 2009 年 6 月份的理化指标未测定.

\section{3 数据分析}

采用大型多元统计软件 PRIMER 5.0 对赣江下游底栖动物群落结构进行 SIMPER ( Similarity Percentages) 和 ANOSIM (Analysis of Similarities) 分析 ${ }^{[10-11]}$, 以揭示其群落结构的时空变化.

另外, 根据赣江下游底栖动物群落结构特点以及采样数据, 选择以下 3 种生物指数进行分析和评价:

Shannon-Wiener 多样性指数: $H^{\prime}=-\sum_{i=1}^{s} P_{i} \log _{2} P_{i}$, Margalef 丰富度指数: $D=(S-1) / \ln N$, Pielou 均匀 性指数: $J=H^{\prime} / \log _{2} S$, 式中, $P_{i}$ 为物种 $i$ 抽样个体数占全部抽样个体总数的比率, $S$ 为物种总数, $N$ 为所有物 种的个体数之和 ${ }^{[12-14]}$. 水质评价标准: $H^{\prime}>3$ 为清洁; $2 \sim 3$ 为轻度污染; $1 \sim 2$ 为中度污染; $0 \sim 1$ 为重度污染. Margalef 丰富度指数水质评价的标准与 Shannon-Wiener 多样性指数一致.

\section{2 结果}

\section{1 赣江下游大型底栖动物群落组成与变化}

赣江下游 3 个时间段内共鉴定到大型底栖动物 25 种,隶属于 3 门 6 纲 11 目 15 科. 其中, 环节动物门 5 种, 节肢动物门 5 种, 软体动物门为 15 种 (表 2). 从种类组成的时间变化趋势来看, 自 2009 年 6 月 (丰水 期）、11 月 (枯水期) 到 2010 年 4 月 (平水期), 种及种上阶元的数量基本呈下降趋势. 其中丰水期为 3 门 6 纲 9 目 12 科 20 种,枯水期为 3 门 5 纲 8 目 11 科 15 种, 平水期为 3 门 5 纲 7 目 10 科 17 种. 从种类组成的空 间变化趋势来看, 支流的 15 个采样点共采集到 3 门 6 纲 11 目 15 科 22 种, 干流的 15 个采样点则共采集到 3 门 6 纲 11 目 12 科 20 种. 从支流到干流, 其科、种级分类单元亦呈下降趋势, 其中对水质要求较高的蜉蝣幼虫、箭 蜓稚虫等类群仅在支流中分布; 而一些较大型软体类动物如洞穴丽蚌、圆背角无齿蚌则仅在干流中分布.

\section{2 赣江下游大型底栖动物密度、生物量的时空变化}

在时间尺度上, 丰水期、枯水期和平水期的大型底栖动物密度、生物量表明 (图 2 ), 密度最大值 $\left(145.9 \pm 81.8 \mathrm{ind} . / \mathrm{m}^{2}\right)$ 出现在 6 月份, 最小值 $\left(89.6 \pm 15.9 \mathrm{ind} . / \mathrm{m}^{2}\right)$ 则出现在 4 月份, 其大小顺序为丰水 期 $>$ 枯水期 $>$ 平水期. SIMPER 分析结果表明这 3 个时期的优势种类组成存在明显区别, 在丰水期, 其优势 种类为摇蚊幼虫和 3 种软体类; 枯水期的优势种则由 5 种软体类组成; 平水期的优势种由摇蚊幼虫、中华颤 蚓和 5 种软体类组成 (表 3). One-Way ANOSIM 分析结果显示, 大型底栖动物群落结构在时间尺度上存在显 著差异, 不相似百分比分别为 $D i s_{\text {丰枯 }}=85.04 \%, D i s_{\text {丰平 }}=86.96 \%, D i s_{\text {枯平 }}=85.93 \%(P=0.019)$. 生物量最大 值 $\left(90.1 \pm 25.4 \mathrm{~g} / \mathrm{m}^{2}\right)$ 与密度正好相反, 出现在 4 月, 最小值 $\left(62.9 \pm 20.9 \mathrm{~g} / \mathrm{m}^{2}\right)$ 出现在 6 月, 其大小顺序为 平水期 $>$ 枯水期 $>$ 丰水期. 
表 2 赣江下游大型底栖动物群落组成及分布 *

Tab. 2 The composition and distribution of macrozoobenthos in lower reaches of Ganjiang River

\begin{tabular}{|c|c|c|c|c|c|c|}
\hline \multirow{2}{*}{ 种名 } & \multicolumn{2}{|c|}{ 丰水期 } & \multicolumn{2}{|c|}{ 枯水期 } & \multicolumn{2}{|c|}{ 平水期 } \\
\hline & 干流 & 支流 & 干流 & 支流 & 干流 & 支流 \\
\hline 中华颤蚓 Tubifex sinicus & ++ & + & & & ++ & + \\
\hline 霍甫水丝蚓 Limnodrilus hoffmeisteri & ++ & + & ++ & + & ++ & ++ \\
\hline 苏氏尾鳃蚓 Branchiura sowerbyi & +++ & + & & & + & + \\
\hline 仙女虫 Nais sp. & + & & + & + & ++ & + \\
\hline 扁蛭 Glossiphonia complanata & & + & + & & & ++ \\
\hline 钩虾 Gammarus sp. & + & + & & & & \\
\hline 划蝽 Sigara sp. & & & & + & & \\
\hline 蜉蝣幼虫 Ephemera $\mathrm{sp}$. & & & & + & & \\
\hline 箭蜓稚虫 Gomphus sp. & & + & & & & \\
\hline 摇蚊幼虫 Chironomus sp. & + & ++ & + & ++ & +++++ & +++ \\
\hline 淡水壳菜 Limnoperna lacustris & +++++ & +++ & +++++ & + & +++ & ++ \\
\hline 蚶形无齿蚌 Anodonta arcaeformis & + & + & + & & + & \\
\hline 圆背角无齿蚌 $A$. woodiana pacifica & & & & & + & \\
\hline 微红楔蚌 Cuneopsis rufescens & + & & + & & + & ++ \\
\hline 洞穴丽蚌 Lamprotula caveata & & & & & + & \\
\hline 中国尖崉蚌 Acuticosta chinensis & + & & + & + & & \\
\hline 河蚬 Corbicula fluminea & ++++ & +++ & +++++ & ++ & +++ & +++ \\
\hline 耳萝卜螺 Radix auricularia & + & & & & & \\
\hline 椭圆萝卜螺 R. swinhoei & & + & & & & + \\
\hline 方格短沟蜷 Semisulcospira cancellata & ++ & ++ & +++ & ++ & + & +++ \\
\hline 梨形环棱螺 Bellamya purificata & ++ & ++ & +++ & +++ & + & ++ \\
\hline 铜锈环棱螺 B. aeruginosa & +++++ & ++ & ++ & ++ & ++++ & +++ \\
\hline 方形环棱螺 B. quadrata & + & + & + & + & & \\
\hline 耳河螺 Rivularia auriculata & & & & & +++ & ++ \\
\hline 大沼螺 Parafossarulus eximius & & + & & & & \\
\hline
\end{tabular}

*空格表示 0 ind. $/ \mathrm{m}^{2} ;+$ 表示 $0 \sim 1.0$ ind. $/ \mathrm{m}^{2} ;++$ 表示 $1.0 \sim 5.0$ ind. $/ \mathrm{m}^{2} ;+++$ 表示 $5.0 \sim 20.0$ ind. $/ \mathrm{m}^{2} ;++++$ 表示 $20.0 \sim 50.0$ ind. $/ \mathrm{m}^{2} ;+++++$ 表示 $>50.0$ ind. $/ \mathrm{m}^{2}$.

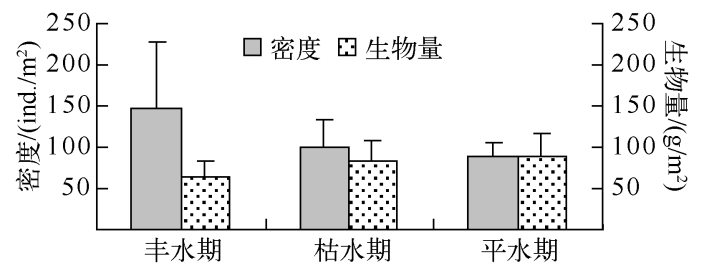

图 2 赣江下游流域大型底栖动物密度 和生物量的时间变化

Fig. 2 Temporal variation of density and biomass of macrozoobenthos in lower reaches of Ganjiang River 流, 在枯水期却低于支流 (图 3a).
在空间尺度上, 3 个采集时间段内, 干流大型 底栖动物的密度均不同程度地高于支流, 而这种差 异在丰水期尤为显著 (图 3a). SIMPER 分析结果显 示干流与支流的优势种类组成存在明显区别, 干流 的优势种完全由 4 种软体类组成, 支流则由摇蚊幼 虫和另外 4 种软体类组成 (表 3), One-Way ANOSIM 分析结果则显示群落结构在空间尺度上存在 显著差异, 不相似百分比为 $D i s_{\text {支干 }}=86.62 \%(P=$ 0.048 ). 而生物量在空间尺度上的变化趋势与密度 不一致,干流的生物量在丰水期和平水期均高于支

\section{3 赣江下游多样性指数的时空变化与水质评价}

Margalef 丰富度指数、Shannon-Wiener 多样性指数和 Pielou 均匀性指数的均值在 3 个采集时间段内均是枯 水期最高、丰水期最低, 这说明赣江下游的大型底栖动物多样性存在季节性变化 (图 $3 \mathrm{~b}$ ). Margalef 丰富度指数 和 Shannon-Wiener 多样性指数在丰水期和平水期均是支流高于干流, 而 Pielou 均匀性指数则在这 3 个采集时 间段内始终是支流高于干流, 这说明支流水质总体优于干流, 且支流大型底栖动物群落结构更加均匀、稳定. 
表 3 赣江下游大型底栖动物优势种平均密度 $\left(\right.$ ind. $\left./ \mathrm{m}^{2}\right)$ 及其对组内相似性贡献百分比的时空变化

Tab. 3 Temporal and spatial variation of the mean density of dominant species for each group and the contribution to within group similarity of the macrozoobenthos in lower reaches of Ganjiang River

\begin{tabular}{|c|c|c|c|c|c|}
\hline \multirow{2}{*}{ 优势物种 } & \multicolumn{3}{|c|}{ 时间变化 } & \multicolumn{2}{|c|}{ 空间变化 } \\
\hline & 丰水期 & 枯水期 & 平水期 & 干流 & 支流 \\
\hline 河蚬 & $17.54(57.95 \%)$ & $21.30(50.43 \%)$ & $15.35(31.85 \%)$ & $23.72(49.72 \%)$ & $13.06(43.06 \%)$ \\
\hline 淡水壳菜 & $23.32(14.04 \%)$ & $41.33(3.95 \%)$ & $6.09(4.82 \%)$ & $46.61(23.02 \%)$ & - \\
\hline 摇蚊幼虫 & $6.99(12.54 \%)$ & - & $28.24(16.69 \%)$ & 一 & $17.10(20.80 \%)$ \\
\hline 铜锈环棱螺 & $86.59(6.22 \%)$ & $5.96(14.74 \%)$ & $15.58(27.57 \%)$ & $64.98(11.42 \%)$ & $9.50(16.98 \%)$ \\
\hline 梨形环棱螺 & - & $18.36(16.95 \%)$ & $2.46(4.21 \%)$ & $11.58(8.14 \%)$ & $4.29(6.32 \%)$ \\
\hline 方格短沟蜷 & 一 & $6.67(7.23 \%)$ & $4.93(4.79 \%)$ & 一 & $4.80(5.43 \%)$ \\
\hline 中华颤蚓 & 一 & - & $3.58(2.57 \%)$ & - & - \\
\hline 合计 & $134.41(90.74 \%)$ & $93.62(93.30 \%)$ & $76.23(92.50 \%)$ & $146.89(92.31 \%)$ & $48.75(92.59 \%)$ \\
\hline
\end{tabular}

根据 Shannon-Wiener 多样性指数和 Margalef 丰富度指数, 赣江下游所有采样点均属于中度污染或重度 污染 (表 4). 其中对于干流的水质评价, Margalef 丰富度指数和 Shannon-Wiener 多样性指数的评价结果完全 一致, 在隶属干流的 15 个采样点中, 重度污染的采样点有 5 个, 所占比例为 $33.3 \%$. 对于支流, 据 ShannonWiener 多样性指数的评价标准, 重度污染的采样点有 3 个, 所占比例为 $20 \%$; 而据 Margalef 丰富度指数评价 标准, 重度污染的采样点有 4 个, 所占比例为 $26.7 \%$. 尽管这 2 种指数对支流水质的评价结果存在一定差 异,但均说明干流的污染程度较支流更为严重.

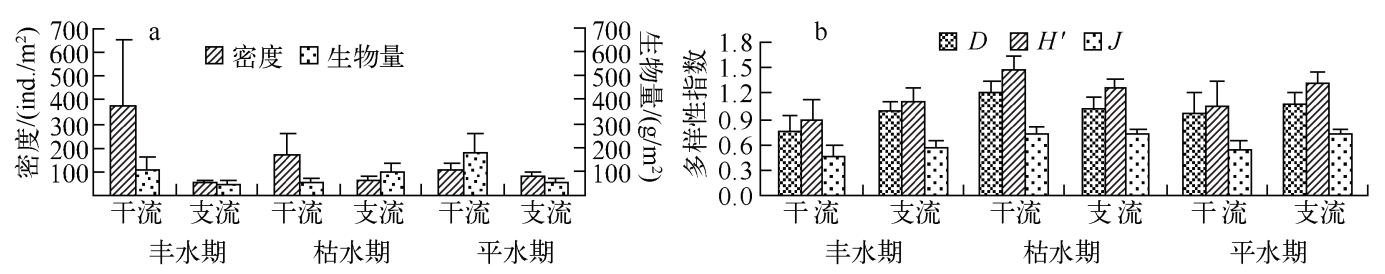

图 3 赣江下游大型底栖动物密度和生物量 ( a) 和 3 种多样性指数 (b) 的时空变化

Fig. 3 Temporal and spatial variations of density and biomass of macrozoobenthos(a) and Margalef index,

Shannon-Wiener index and Pielou evenness $\operatorname{index}(b)$ in lower reaches of Ganjiang River

表 4 竷江下游各采样点的水质生物评价结果

Tab. 4 The biologic evaluation of water quality at each sampling site in the lower reaches of Ganjiang River

\begin{tabular}{|c|c|c|c|c|c|}
\hline \multirow{2}{*}{\multicolumn{2}{|c|}{ 水质评价 }} & \multicolumn{2}{|c|}{ Shannon-Wiener 多样性指数 $\left(H^{\prime}\right)$} & \multicolumn{2}{|c|}{ Margalef 丰富度指数 $(D)$} \\
\hline & & \multirow[t]{2}{*}{ 干流 } & \multirow[t]{2}{*}{ 支流 } & \multirow[t]{2}{*}{ 干流 } & \multirow[t]{2}{*}{ 支流 } \\
\hline 清洁 & $>3.0$ & & & & \\
\hline 轻度污染 & $2.0 \sim 3.0$ & & & & \\
\hline \multirow[t]{2}{*}{ 中度污染 } & $1.0 \sim 2.0$ & $16^{\#} 、 17^{\#}, 19^{\#}, 22^{\#} 、 24^{\#} 、$ & $1^{\#} \sim 4^{\#} 、 6^{\#} \sim 10^{\#} 、$ & $16^{\#} 、 17^{\#}, 19^{\#}, 22^{\#}, 24^{\#}$ & $1^{\#} \sim 4^{\#} 、 7^{\#}, 8^{\#}$ \\
\hline & & $25^{\#} 、 26^{\#} 、 28^{\#}, 29^{\#}, 30^{\#}$ & $12^{\#} \sim 14^{\#}$ & $25^{\#} 、 26^{\#}, 28^{\#} 、 29^{\#}, 30^{\#}$ & $10^{\#}, 13^{\#}, 14^{\#}$ \\
\hline 重度污染 & $<1.0$ & $18^{\#} 、 20^{\#} 、 21^{\#}, 23^{\#}, 27^{\#}$ & $5^{\#}, 11^{\#}, 15^{\#}$ & $18^{\#} 、 20^{\#}, 21^{\#}, 23^{\#}, 27^{\#}$ & $5^{\#}, 9^{\#}, 11^{\#}, 15^{\#}$ \\
\hline
\end{tabular}

\section{3 讨论}

底栖动物的物种数量和分布格局受温度、底质类型、水体理化性质等众多气候因子与环境因子的综合 影响与制约, 这些因子的季节性变化进而导致底栖动物群落结构在不同季节间存在差异 ${ }^{[1-2,15]}$. 赣江下游底 栖动物的种及种上阶元的分类单元数从丰水期、平水期到枯水期总体呈下降趋势, 与其水体深度的变化相 
关, 有研究表明水位的深浅对底栖动物的种类数量和群落结构存在显著影响 ${ }^{[15-16]}$. 而对于赣江下游来说, 其 枯水期的水位较平水期平均下降 1 2 $\mathrm{m}$ (表 1), 其中 $15^{\#}$ 采样点在枯水期甚至完全干涸断流而无法采样, 这 更能说明水位下降对底栖动物的影响. 从地理位置上看, 由于支流通常位于上游, 其水体理化性质、底质类 型、受污染程度等众多特征与干流存在差异, 这通常导致支流与干流之间的底栖物种组成不同 ${ }^{[17]}$, 且支流物 种数量通常比干流更为丰富 ${ }^{[18-19]}$. 赣江下游从支流到干流, 其分类单元呈现下降趋势这一现象与其它河流 干、支流底栖动物的调查结果相一致 ${ }^{[18-19]}$. 支流在溶解氧、浊度、 $\mathrm{pH}$ 值等多项理化指标上均优于干流 (表 1), 这些理化指标均是许多大型底栖动物分布的限制性因子 ${ }^{[20]}$, 从而使得蜉蝣幼虫、蜻蜓稚虫等对水质敏感的 类群均仅在支流出现,增大了支流的物种数量, 该结果与其它相关研究结果相符 ${ }^{[17-18]}$.

在季节变化方面,赣江下游大型底栖动物的密度最高值出现在初夏的丰水期,枯水期次之,而平水期最 低. 有研究表明,底栖动物的密度在不同水体中,其季节性变化也不相一致,其最高值可以出现在秋、冬季 节 $^{[1-2,21]}$, 亦可出现在春、夏季节 ${ }^{[22-25]}$. 这种季节上的差异既与不同类群的生活史特征密切相关 ${ }^{[26]}$, 也与不同 水体其自身所处的气候环境所决定, 即气候环境对底栖动物群落结构产生影响, 进而影响到生物密度的变 化 $^{[2]}$. 赣江流域属中亚热带湿润季风气候区 ${ }^{[4]}$, 夏季初期正值节肢动物幼虫生长高峰期, 这就大大增加了底 栖动物的生物密度, 从丰水期优势物种的构成上亦可以得到印证. 在丰水期, 摇蚊幼虫成为众多优势种类之 一, 而在枯水期, 其优势种类则完全由软体类动物构成, 正是由于优势种类构成的季节性变化导致了生物密 度与生物量的最高值在时间上出现不同步现象 ${ }^{[21,27]}$. 就生物量而言, 其最高值并未出现在优势种类全部为 软体类的枯水期, 这是因为其中有相当一部分为淡水壳菜, 作为一种小型的软体类动物, 中其平均体重仅为 $0.1044 \mathrm{~g} /$ ind. . 在平水期,虽然其优势种有一部分为摇蚊幼虫和中华颤蚓，但仅在此期间出现的洞穴丽蚌 (19.25 g/ind.) 、圆背角无齿蚌 (53.18 g/ind.) 等大型软体类动物显著弥补了前 2 个物种在生物量上的劣 势, 从而使得生物量的最高值出现在平水期.

在空间变化方面,赣江下游大型底栖动物的密度和生物量在丰水期、枯水期和平水期均是干流不同程度 地高于支流, 在丰水期尤为显著,这种差别可能是由于干、支流的底质类型不同所造成的 ${ }^{[1]}$. 属于干流的 15 个 采样点均处在下游, 由于冲刷沉积作用, 其底质多属于泥沙类型, 比较适合软体类动物的分布 ${ }^{[28]}$, 而软体类正 是构成生物量的主要成分, 这必然会增大干流的生物量. 实际上, 洞穴丽蚌、圆背角无齿蚌等较大型软体类只 在干流有分布 (表 2) 也充分解释了这一现象. 同时, 从支流上游冲刷下来的有机质在下游干流河道中沉积后, 有利于臭毛类和摇蚊幼虫等类群的生长 ${ }^{[1]}$, 使得干流的这 2 个类群的数量在 3 个时间段内均不同程度地高于 支流 (表 2), 这也明显增大干流大型底栖动物密度. 支流则均位于上游, 水质较为清澈, 底质多为粗砂加砾石类 型, 不利于软体类动物的分布, 其生物密度和生物量通常低于干流 ${ }^{[1]}$. 另外, 粗砂加砾石类型的底质不利于采 样过程中采泥器的抓取,也有可能导致一部分标本的流失, 从而进一步降低了支流的生物量和密度.

对赣江下游底栖动物的多样性指数进行计算,结果表明 Shannon-Wiener 多样性指数、Margalef 丰富度指 数和 Pielou 均匀性指数均出现季节性变化, 在对香河、汉江等河流的研究中亦有类似结果出现 ${ }^{[15,21]}$. 在枯水 期,3 个多样性指数均最高, 这是因为在此期间采集的样本中有划蝽、蜉蝣、蜻蜓稚虫等稀有种类, 这些种类 的存在增加了物种多样性与丰富度; 而在丰水期, 季节性洪水的暴发导致河流底栖动物群落物种多样性显 著减少 ${ }^{[29-31]}$, 这正是丰水期 3 个多样性指数均最低的重要原因. 就干、支流而言, 赣江下游支流的 3 个多样 性指数总体上均高于干流, 这种现象在其它河流中也有类似结果 ${ }^{[17-19]}$. 造成这一现象的原因应与河道底质 类型 ${ }^{[1,28]}$ 、水体的理化性质 ${ }^{[1,17,20]}$ 以及人类活动干扰 ${ }^{[18]}$ 等众多因素有关, 这也说明赣江下游支流的底栖动物 群落组成更加多样、均匀和稳定.

目前, 国外众多水质生物评价的指数当中, 绝大多数是基于大型底栖无脊椎动物、鱼类和藻类建立的, 我国学者也是首选大型底栖动物作为河流水质生物评价的指示生物, 其评价结果亦被广泛接受 ${ }^{[3]}$. 根据 Shannon-Wiener 多样性指数、Margalef 丰富度指数对赣江下游流域 30 个采样点的水质生物学评价结果表明, 整个赣江下游流域水质已经受到不同程度的污染, 其中多数属中度污染, 部分已经达到重度污染程度. 就 干、支流而言, 干流受污染的程度要明显高于支流, 这应与干流流经众多大中城市有关, 城市居民生活和工 业生产等均会对干流产生严重污染 ${ }^{[18]}$. 为了保护赣江底栖动物多样性资源, 有关管理部门应针对干、支流的 具体情况制订不同管理措施. 在支流上游应着力保护原生植被不受破坏以净化水源, 在干流流经的城市则 应加强市区排污的管理以减少污染源. 同时, 鉴于整个沿江两岸采砂作业日益严重, 有关部门应合理安排、 科学指导沿江的采砂活动,这对保护底栖动物栖息、繁殖场所亦至关重要. 


\section{4 参考文献}

[ 1 ] 刘建康. 高级水生生物学. 北京: 科学出版社, 1999.

[2] 渠晓东. 香溪河大型底栖动物时空动态、生物完整性及小水电站的影响研究 [学位论文]. 武汉: 中国科学院水生 生物研究所, 2006.

[ 3 ] 吴东浩, 王备新, 张 咏等. 底栖动物生物指数水质评价进展及在中国的应用前景. 南京农业大学学报, 2011, 34(2) : 129-134.

[ 4 ] 王毛兰, 周文斌, 胡春华. 赣江流域水体无机氮分布特征. 南昌大学学报, 2007, 31(3): 271-275.

[ 5] 方红亚, 张方方, 张 萌等. 赣江流域袁河底栖动物群落结构及其水质生物学评价. 安徽农业科学, 2011, 39 (4) : 2254-2257.

[ 6 ] Morse JC, Yang LF, Tian LX. Aquatic insects of China useful for monitoring water quality. Nanjing: Hohai University Press, 1994.

[ 7 ] 刘月英. 中国经济动物志一一淡水软体动物. 北京: 科学出版社, 1979 .

[8] 陈 义. 中国动物图谱一一环节动物. 北京: 科学出版社, 1959 .

[ 9 ] 梁象秋, 方纪祖, 杨和荃. 水生生物学(形态和分类). 北京: 中国农业出版社, 1995.

[10] 周 红, 张志南. 大型多元统计软件 PRIMER 的方法原理及其在底栖群落生态学中的应用. 青岛海洋大学学报, $2003,33(1)$ : $58-64$.

[11] Clarke KR. Non-parametric multivariate analyses of changes in community structure. Australian Journal of Ecology, 1993, 18: 117-143.

[12] Shannon CE, Wiener W. The mathematical theory of communication. Urbana: University of Illinois Press, 1949.

[13] Margalef DR. Information theory in ecology. Generation Systems, 1957, 3: 36-71.

[14] Pielou EC. The measurement of diversity in different types of biological collections. Journal of Theoretical Biology, 1966, 13: 131-144.

[15] 蒋万祥, 贾兴焕, 周淑婵等. 香溪河大型底栖动物群落结构季节动态. 应用生态学报, 2009, 20 (4) : 923-928.

[16] Brooks AJ, Haeusler T, Reinfelds I et al. Hydraulic microhabitats and the distribution of macroinvertebrate assemblages in riffles. Freshwater Biology, 2005, 50(2) : 331-344.

[17] 渠晓东, 曹 明, 郡美玲等. 雅砻江 (锦屏段) 及其主要支流的大型底栖动物. 应用生态学报, 2007, 18 (1): 158-162.

[18] 曹艳霞, 蔡德所, 张 杰等. 漓江水系大型无脊椎底栖动物多样性现状调查. 广西师范大学学报: 自然科学版, $2009,27(2): 118-123$.

[19] 赵伟华, 刘学勤. 西藏雅鲁藏布江雄村河段及其支流底栖动物初步研究. 长江流域资源与环境, 2010, 19(3): 281-286.

[20] Naiman RJ, Bilby RE. River ecology and management. New York: Springer, 2001: 169-199.

[21] 间云君, 李晓宇. 汉江流域上游支流大型底栖动物群落结构特征与生物多样性. 湖泊科学, 2007, 19(5): 585-591.

[22] 周 晓, 葛振明, 施文或等. 长江口九段沙湿地大型底栖动物群落结构的季节变化规律. 应用生态学报, 2006, 17(11) : 2079-2083.

[23] 张凤英, 庄 平, 徐兆礼. 长江口中华鲟自然保护区底栖动物. 生态学杂志, 2007, 26 (8) : 1244-1249.

[24] 张 敏, 郡美玲, 蔡庆华等. 丹江口水库大型底栖动物群落结构及其水质生物学评价. 湖泊科学, 2010, 22 (2): 281-290.

[25] Pliuraite V. The seasonal change of macrozoobenthos in the Merkys River in 1998. Acta Zoologica Lituanica, 2001, 11 (1) : 39-52.

[26] Pennak RW. Freshwater invertebrates of the USA. New York: Ronald Press Company, 1953.

[27］刘宝兴, 由文辉. 苏州河大型底栖动物群落结构变化. 生态与农村环境学报, 2006, 22 (3) : 23-28.

[28] 陈其羽, 梁彦龄, 宋贵宝等. 武昌东湖软体动物的生态分布及种群密度. 水生生物学集刊, 1975, 5 (3) : 371-379.

[29] Lamberti GA, Gregory SV, Ashkenas LR et al. Stream ecosystem recovery following a catastrophic debris flow. Canadian Journal of Fisheries and Aquatic Sciences, 1991, 48: 196-208.

[30] Brewin PA, Buckton ST, Ormerod SJ. The seasonal dynamics and persistence of stream macroinvertebrates in Nepal: do monsoon floods represent disturbance? Freshwater Biology, 2000, 44: 581-594.

[31] Death RG. The effect of floods on aquatic invertebrate communities. In: Lancaster J, Briers RA eds. Aquatic insects: challenges to populations. Trowbridge: Cromwell Press, 2008: 103-121. 